\title{
KOMPETENCJE POCZĄTKUJĄCEGO NAUCZYCIELA JĘZYKA ANGIELSKIEGO W ŚWIETLE MODELU KARDS B. KUMARAVADIVELU
}

\section{Competences of the novice English teacher in the light of B. Kumaravadivelu's KARDS model}

\begin{abstract}
This article focuses on first-year English teachers' competences from the perspective of teachers themselves. The point of reference is offered by $B$. Kumaravadivelu's (2012) language teacher education KARDS model (KNOWING, ANALYSING, RECOGNIZING, DOING and SEEING), which is based on cognitive and social constructivism. Providing an answer to progressing economic and educational globalization, the model stresses the need for verification of what contemporary language teachers' competences constitute, For this reason the study described in the article seeks to find out how the competences of first-year teachers, as seen by the teachers themselves, match the requirements suggested in the model.
\end{abstract}

\section{Wstęp}

W literaturze glottodydaktycznej różne aspekty kompetencji nauczycieli języków obcych doczekały się licznych opracowań, prób klasyfikacji i porządkowania znaczeń. Wystarczy wymienić ważne publikacje międzynarodowe ostatnich piętnastu lat podejmujące zagadnienia świadomości nauczyciela (Woods, 1996; Borg, 2006; Andrews, 2007), rozwoju zawodowego (Johnson, 2009; Johnson i Golombek, 2011), refleksji (Farrell, 2007), narracji nauczycielskich (Johnson i Golombek, 2002; Kalaja, Menezes i Barcelos, 2010), wartości (Johnston, 2003), doświadczenia (Senior, 2006; Garton i Richards, 2008), a pisane z perspektywy polskiego kontekstu edukacyjnego monografie Wysockiej 
(1998; 2003), Zawadzkiej (2004), Werbińskiej (2004; 2009; 2011), Poloka (2010), aby dostrzec, jak wiele elementów pracy nauczyciela zajmuje uwagę badaczy. Jednak sam termin „kompetencja” jest wieloznaczny - niekiedy oznacza rodzaje wiedzy, którymi dysponuje nauczyciel języka obcego, czasami jest równoznaczny z pojęciem roli nauczyciela, a w jeszcze innych publikacjach pojęciem „kompetencja” określa się rzetelne wykonywanie powinności nauczyciela, a nawet posiadanie kwalifikacji do zawodu. Choć nie ma zgody na jednoznaczne rozumienie terminu, „kompetencja” niewątpliwie stanowi rodzaj kluczowego pojęcia rzutującego na kształt edukacji i dlatego refleksja nad jakimkolwiek aspektem edukacji powinna być w znacznej mierze refleksją nad edukacją nauczycieli, w tym ich kompetencjami wpływającymi na sposób formułowania celów edukacyjnych i sposobów ich realizacji.

Przedmiotem niniejszego opracowania są kompetencje początkujących nauczycieli języka angielskiego z perspektywy samych nauczycieli, a punktem odniesienia jest osadzenie rozważań w kontekście modelu KARDS zaproponowanego przez B. Kumaravadivelu (2012). Oparty na konstrukcjonizmie poznawczym i społecznym, model Kumaravadivelu jest odpowiedzią na dokonujące się przemiany społeczno-kulturowe oraz postępującą globalizację ekonomiczną i edukacyjną, które wymagają radykalnego przeformułowania myślenia na temat kompetencji nauczycieli. Z tego względu, próba oglądu kompetencji nauczyciela języka angielskiego $w$ pierwszym roku pracy $w$ tym ujęciu wydaje się ważna i ciekawa.

\section{Model KARDS jako podłoże teoretyczne badania kompetencji nauczyciela}

Nowy globalny i nieustannie zmieniający się kontekst wymusza spojrzenie na edukację z perspektywy „po”. Tym samym, Kumaravadivelu proponuje pięć takich ujęć, zwanych przez niego „post”, sprowadzających się do następujących pięciu perspektyw: postnarodowej, postmodernistycznej, postkolonialnej, post-transmisyjnej i post-metodycznej. Trzy pierwsze z nich odnoszą się do szerokiego kontekstu historyczno-społecznego, zaś dwie ostatnie do kompetencji nauczycieli języków obcych i dlatego poświęcimy im naszą uwagę.

Podejście nauczyciela do nauczania znajduje odzwierciedlenie $w$ realizowanym modelu edukacji, postrzegania wiedzy, roli jednostki i stylu myślenia (por. Nowak-Łojewska, 2011: 129). Podejście transmisyjne w tym sensie oznacza edukację instrumentalną, rządzoną jednym „poprawnym” schematem myślenia, narzucanym przez wszechwiedzącego nauczyciela i z góry ustalony program szkolny uczniowi pełniącemu rolę „reaktywnego wykonawcy i bierne- 
go rejestratora oczekiwań zewnętrznych; odtwórcy standardów i realizatora wytycznych" (ibid.). Natomiast podejście post-transmisyjne przyznaje indywidualny charakter procesowi akwizycji języka obcego, w którym nauczyciel, obdarzony intuicją, empatią i dobrą znajomością kontekstu edukacyjnego zachęca ucznia do samodzielnego poszukiwania znaczeń i emancypacyjnego, a nie adaptacyjnego, stylu myślenia, a jako transformacyjny intelektualista dąży nie tylko do akademickich postępów, lecz także do osobistej transformacji, zarówno swojej, jak i uczniów. Można powiedzieć, że podejście posttransmisyjne jest przekierowaniem edukacji nauczycieli z nauczania opartego na informacjach na nauczanie oparte na poszukiwaniu, gdzie ostatecznym celem jest wygenerowanie samosterownych i autonomicznych jednostek.

Stosowane przez nauczyciela metody nauczania języków obcych są wciąż postrzegane jako gwarancje skutecznego nauczania. Choć ogólnie wiadomo, że żaden nauczyciel nie realizuje metody nauczania języka obcego stuprocentowo w "czystej” formie, jak również że pojawiają się liczne krytyczne uwagi pod adresem konkretnych metod i koncepcji metody w ogóle, wiele osób zajmujących się edukacją nadal patrzy na nauczanie języków obcych przez pryzmat stosowanej metody. Podejście post-metodyczne z kolei zakłada, że sam nauczyciel wie, co sprawdza się w przypadku jego uczniów, a tym samym promuje refleksyjne myślenie nauczycieli, umiejętność analizy i ewaluacji praktyki nauczania, inicjowanie zmian w klasie szkolnej oraz monitorowanie efektów. Takie podejście opowiada się za nauczycielami strategami oraz strategicznymi badaczami, którzy nie wykonują służalczo zaleceń decydentów oświatowych, lecz redefiniują je i modyfikują do swoich potrzeb, dając wyraz swojej autonomii działania w obliczu ograniczeń instytucjonalnych, programowych i podręcznikowych.

Można powiedzieć, że wszystkie ujęcia „post” łączy stanowisko „posttradycyjne", a więc zakwestionowanie pewności i obiektywizmu, na rzecz aktywności, konstruowania i osobistego wykrywania znaczeń, twórczego i krytycznego myślenia oraz interakcji jednostki z otoczeniem (NowakŁojewska, 2011: 101).

Aby znaleźć uznanie w oczach praktyków, wszelkie modele edukacji muszą dostarczać poczucia kierunku, jak również wsparcia niezbędnego do przekładania przekonań, wartości czy oczekiwań nauczycieli na realistyczne plany i mierzalne wyniki. Kumaravadivelu (2012: 11) proponuje trzy zasady operacyjne: szczegółowości, praktyczności i możliwości. Zasada szczegółowości oznacza, że koncepcja pedagogiczna musi dać się zastosować w lokalnych, konkretnych, społeczno-kulturowych kontekstach, w których proces nauczania i uczenia się ma miejsce. W przeciwnym razie, jej użyteczność mija się z celem. Zasada praktyczności zakłada, że kompetencje pedagogiczne muszą wypływać 
z codziennej praktyki. Oznacza to, że tylko wtedy, gdy nauczyciele teoretyzują swoje praktyczne działania w klasie, mogą dokonywać własnych eksploracji. Zasada możliwości natomiast to traktowanie doświadczeń zdobytych w klasie jako źródeł formowania indywidualnych tożsamości, poszukiwań własnych ja i samorozwoju. Nie ma tutaj miejsca na przekazywanie nieaktualnej wiedzy w sposób transmisyjny, zaś świadomość społeczno-polityczna może pomóc w kształtowaniu osobistych i społecznych tożsamości. Wszystkie trzy zasady eksponują wiedzę osobistą kosztem wiedzy podanej, własną sprawczość kosztem autorytarnego kontrolowania zdarzeń dydaktycznych, lokalność kosztem globalności, aktywność i podmiotowość z prawem do własnego zdania kosztem pasywności i reaktywności. Zarówno omawiane wcześniej perspektywy, jak i zasady wymienione powyżej dostarczają koncepcyjnego podłoża dla modelu KARDS w edukacji nauczyciela języka obcego, w oparciu o który będziemy rozpatrywać kompetencje początkującego nauczyciela.

Model KARDS składa się z pięciu modułów, przedstawionych tutaj w formie czasowników: wiedzieć (KNOWING), analizować (ANALYSING), rozpoznawać (RECOGNIZING), wykonywać (DOING) i patrzeć (SEEING). Kumaravadivelu (2012: 17) twierdzi, że dobór komponentów odzwierciedla kompetencje nauczyciela języka obcego potrzebnego współczesnym czasom, a więc takiego, który (1) rozwija się merytorycznie, (2) analizuje potrzeby, motywacje, autonomiczność uczniów, (3) rozpoznaje swoje własne wartości, przekonania, refleksje, (4) naucza, obserwuje i teoretyzuje, (5) monitoruje swoje własne działania pedagogiczne. Tabela 1 przedstawia adaptację modelu z uwzględnieniem kompetencji szczegółowych początkujących nauczycieli. W zaproponowanym modelu dwie ważne kwestie należy odnotować. Po pierwsze, brak jest w nim precyzyjnie wyspecyfikowanych czynności nauczyciela, które sprawdzają się wyłącznie w sytuacjach stałych, powtarzalnych i z góry określonych, rzadko występujących w zawodzie nauczyciela. Po drugie, wszystkie wymienione kompetencje szczegółowe cechuje moc inferencyjna (Kwiatkowska, 2010: 78), a więc „zdolność tworzenia nowych informacji z zasobów wiedzy już posiadanej”, nie odtwarzanej, nie przypominanej, lecz kreowanej „pod wpływem refleksji i rozpoznawania dziejących się zdarzeń i ich definiowania" (ibid.). Tylko w modelu uwzględniającym powyżej wymienione czynniki, a nade wszystko odejście od transmisji na rzecz transformacji, nauczyciel języka obcego może rozwinąć holistyczne rozumienie tego, co dzieje się w jego klasie. Wówczas prawdopodobnie będzie mógł formułować swoje teorie na podstawie odbywanej praktyki oraz wprowadzać w praktykę to, co głosi w teorii. 
Kompetencje początkującego nauczyciela języka angielskiego w świetle modelu...

\begin{tabular}{|c|c|}
\hline Kompetencje ogólne & Kompetencje szczegółowe \\
\hline \multirow[t]{3}{*}{ Wiedzieć } & - odznaczać się dobrą znajomością nauczanego języka \\
\hline & $\begin{array}{l}\text { - odznaczać się dobrą znajomością teorii uczenia się i nauczania } \\
\text { języków }\end{array}$ \\
\hline & - umiejętnie zarządzać uczeniem się w klasie \\
\hline \multirow[t]{3}{*}{ Analizować } & - diagnozować potrzeby uczniów \\
\hline & - utrzymywać motywację uczniów do uczenia się \\
\hline & - wdrażać autonomię uczenia się \\
\hline \multirow[t]{3}{*}{ Rozpoznawać } & - rozwijać nauczycielską tożsamość \\
\hline & - mieć świadomość własnych przekonań \\
\hline & - mieć świadomość własnych wartości \\
\hline \multirow[t]{3}{*}{ Działać } & - stwarzać okazje do uczenia się \\
\hline & - inspirować transformacje uczniów \\
\hline & - teoretyzować i prowadzić dialog \\
\hline \multirow[t]{3}{*}{ Patrzeć } & - patrzeć z perspektywy ucznia (Co czuje uczeń?) \\
\hline & $\begin{array}{l}\text { - patrzeć z perspektywy nauczyciela (Jakie role, zachowania promuje } \\
\text { nauczyciel?) }\end{array}$ \\
\hline & - patrzeć z perspektywy obserwatora (Co widzą inni?) \\
\hline
\end{tabular}

Tabela 1: Kompetencje szczegółowe początkujących nauczycieli na podstawie modelu KARDS.

\section{Charakterystyka projektu badawczego}

\subsection{Cele}

Zasadniczym celem przeprowadzonego projektu badawczego była próba zidentyfikowania i lepszego zrozumienia kompetencji nauczycieli języka angielskiego w pierwszym roku pracy. Centralnym zagadnieniem poszukiwań badawczych uczyniono poznanie sposobów konceptualizowania kompetencji początkujących nauczycieli języka angielskiego przez samych nauczycieli, a następnie przypisanie ich komponentom - kompetencjom składającym się na model KARDS. Tym samym, obszarem badań stała się sfera świadomości nauczycieli z intencją opisania zawartych w niej znaczeń, a w konsekwencji wykrycia ich postrzegania kompetencji potrzebnych współczesnemu nauczycielowi. Ściśle mówiąc, problemy badawcze przyjęły postać następujących pytań odnoszących się do dwóch etapów referowanego projektu:

1) Jak nauczyciele języka angielskiego w pierwszym roku pracy konceptualizują swoje kompetencje i jaki nadają im sens?

2) Które komponenty modelu KARDS przekładają się na kompetencje badanych nauczycieli?

Przyjęto, że uzyskanie odpowiedzi na powyższe pytania dostarczy pośrednio informacji na temat tego, jacy są polscy nauczyciele na starcie kariery zawodowej, jak należy kształcić kandydatów na nauczycieli języków obcych i gdzie znajdują się braki. 


\subsection{Uczestnicy}

Uczestnikami badania było 6 nauczycieli języka angielskiego w pierwszym roku pracy. Choć można krytykować małą liczbę osób, należy wspomnieć, że opisywane badanie odbiega od tradycji badań ilościowych, za cel stawia sobie próbę zidentyfikowania i zrozumienia problemu, a nie przeprowadzenia analiz statystycznych w celu wykazania prawidłowości. Próba badawcza tworzona jest tutaj na podstawie wyjątkowości badanych osób, a nie respondentów masowo biorących udział w badaniu. Wszyscy nauczyciele zostali dobrani na podstawie metody śnieżnej kuli, co oznacza że każda osoba wskazuje na inne osoby, które można zbadać. Procedura ta jest stosowana głównie w sytuacjach, w których dostęp do badanych jest trudny (Borg, 2012: 16). Tym samym, rozpoczynając badania od trzech byłych studentek, udało się autorce dotrzeć do trzech innych osób. Cztery osoby spośród badanych pracowały w szkołach publicznych, zaś dwie w szkołach społecznych. W grupie badanych znalazł się jeden mężczyzna. Wobec badanych zastosowano dwa kryteria: konieczność bycia nauczycielem języka angielskiego $\mathrm{w}$ pierwszym roku pracy oraz wyrażenie zgody na udzielenie około 2-godzinnego wywiadu. Wszystkie wywiady przeprowadzono indywidualnie, zarejestrowano elektronicznie i poddano transkrypcji. Dodatkowo, pięcioro badanych zgodziło się na obserwacje swoich lekcji przez autorkę. Obserwacja nie była jednak zasadniczym wymogiem badania, lecz dodatkową możliwością poszerzenia pola badań.

\subsection{Metoda}

Metodą badań zastosowaną w pierwszym etapie był wywiad otwarty, zwany także semi-strukturyzowanym. Taki typ wywiadu nie zakłada powtarzalności pytań oraz nie przywiązuje się w nim wagi do kolejności zadawanych pytań. Prowadzący badanie dysponuje jedynie przewodnikiem do wywiadu zawierającym pytania podtrzymujące i ukierunkowujące tok rozmowy, ale nie wszystkie pytania traktuje się jako obligatoryjne. Takie przeprowadzenie wywiadu pozwala uchwycić to, co rzeczywiście badany chce przekazać, a nie zweryfikować hipotezę podjętą przez niego uprzednio (Nowak-Łojewska, 2011: 226). Nieodłącznym elementem procedury badawczej jest więc prośba o objaśnienie czy uzupełnienie wypowiedzi podczas nagrywania wywiadów (ibid.).

W etapie pierwszym pytania podzielono na kilka grup tematycznych: A. Nauczyciel na wejściu, B. Nauczyciel a nauczanie, C. Nauczyciel a uczniowie, D. Nauczyciel a inne osoby, E. Nauczyciel a wymagania szkoły, F. Nauczyciel w trakcie pierwszego roku pracy. W każdej grupie wyszczególniono pytania obligatoryjne, zapisane poniżej kursywą oraz pytania dodatkowe, podane 
w nawiasach. Dobór pytań opracowano na podstawie przestudiowania literatury dotyczącej początkujących nauczycieli (Bullough, 2009; Farrell, 2006; Farrell, 2008; Schuck et al., 2012). Plan wywiadu wyglądał następująco:

A. Jak to się stało, że został/a Pan/i nauczycielem? (Czy zawsze chciał/a Pan/i zostać nauczycielem? Czy miał Pan/i mistrzów wśród byłych nauczycieli?, Czy ktoś z rodziny jest nauczycielem?, Jakie miał/a Pan/i wyobrażenia o szkole?)

B. Co w szkole się sprawdza, a co nie? Których sprawności i podsystemów naucza Pan/i najczęściej, a których najrzadziej? (Najtrudniejsza sytuacja dydaktyczna w szkole?)

C. Czy dużo Pan/i wie o swoich uczniach? (Czy często Pan/i myśli o uczniach? Najtrudniejsza sytuacja wychowawcza w szkole?)

D. Jak układajq się relacje z dyrekcja, innymi nauczycielami, rodzicami? (Jaka jest Pana/i pozycja w szkole?, Jak wygląda współpraca z opiekunem stażu?)

E. Jak sobie Pan/i radzi z formalnymi aspektami pracy szkoły? (Czy ktoś udzielił pomocy?)

F. Czy chce Pan/i wykonywać pracę nauczyciela? Co to znaczy być nauczycielem? (Czy miał/a Pan/i wątpliwości?, Czy jest Pan/i niezależny/a?, Kiedy może Pan/i stwierdzić, że dzień/ lekcja była udana?)

Grupa A miała charakter otwierający, a jej zasadniczym celem było lepsze poznanie nauczyciela, jak również nawiązanie kontaktu. Odpowiedzi na pozostałe pytania były brane pod uwagę przy analizie uzyskanych danych.

Drugi etap projektu badawczego polegał na skonfrontowaniu uzyskanych danych od nauczycieli z kompetencjami szczegółowymi modelu KARDS w celu zidentyfikowania, które z nich i w jakim zakresie pojawiły się w wypowiedziach respondentów.

\subsection{Analiza danych}

Intencją analizy było skonstruowanie znaczeń odnośnie do rozumienia kompetencji początkujących nauczycieli języków obcych z uwzględnieniem podobieństw i różnic pomiędzy indywidualnymi koncepcjami respondentów. Przyjęto, że w wyniku analizy danych uda się sporządzić kategorię opisu właściwą dla respondentów, wyłonioną w oparciu o ich koncepcje kompetencji. Warto przy tym podkreślić, że przedmiotem analizy nie były jednostkowe wypowiedzi poszczególnych osób, ponieważ „wypowiedź indywidualnego podmiotu ... może zawierać różne koncepcje tego samego zjawiska" (Męczkowska, 2002: 27), lecz „wyeksponowanie odmiennych koncepcji zjawiska oraz ujednolicenie ... a więc różniących się jedynie swoimi zakresami" (ibid.). Dlatego cały 
materiał (6 wywiadów) potraktowano łącznie w celu uchwycenia zjawiska i dokonania jego generalizacji w opiniach uczestników projektu.

Procedura analizowania danych wyglądała następująco:

1. Poznanie całego materiału polegające na przeczytaniu wszystkich wywiadów, ze szczególnym zwróceniem uwagi na pojawiające się odniesienia do kompetencji początkujących nauczycieli języków obcych.

2. Zredukowanie tematów polegające na porządkowaniu wypowiedzi według przypisywanych znaczeń odnoszących się do rozumienia kompetencji dla poszczególnych badanych.

3. Szukanie podobieństw i różnic polegające na porównywaniu znaczeń dotyczących kompetencji początkujących nauczycieli języków obcych utworzonych przez wszystkich badanych.

4. Grupowanie polegające na nazwaniu różnych przejawów uzyskanych koncepcji obejmujących odrębne sposoby rozumienia kompetencji badanych nauczycieli.

5. Utworzenie map sposobów rozumienia kompetencji dla badanej grup.

6. Przyporządkowanie znaczeń występujących w kategoriach opisu kompetencjom modelu KARDS.

\section{Wyniki}

Centralnym rezultatem poznawczym całego badania było utworzenie map sposobów rozumienia kompetencji początkujących nauczycieli języków obcych w świetle doświadczeń respondentów. Taka mapa umożliwia poznanie różnych koncepcji tego samego zjawiska („pluralność sposobów doświadczania świata” Męczkowska 2002) wyłonionych w toku przeprowadzonych wywiadów badawczych wśród nauczycieli oraz odpowiedzi uzyskanych od ich zwierzchników.

\section{Etap I}

Punktem wyjścia do powstania mapy w etapie I było pogrupowanie sensów nadanych przez wszystkich badanych nauczycieli, poprzedzone czasochłonnym porównywaniem poszczególnych wypowiedzi, zmienianiem liczb i nazw wyłonionych kategorii oraz kwalifikowaniem uzyskanych znaczeń do ostatecznych kategorii mapy semantycznej. W rezultacie otrzymano 9 kategorii rozumienia kompetencji: umiejętności językowe, umiejętność nauczania, utrzymywanie dobrych relacji z uczniami, utrzymywanie dobrych relacji z innymi pracownikami szkoły, utrzymywanie dobrych relacji z rodzicami, umiejętności organizacyjne, umiejętność dokonywania refleksji, samodzielne podejmowanie decyzji, radzenie sobie z wymogami formalnymi, zaś każda z kompetencji zawiera 
Kompetencje początkującego nauczyciela języka angielskiego w świetle modelu...

w sobie różnorodne doświadczenia wszystkich respondentów, ich konceptualizacje zgromadzone na podstawie materiału badawczego (Tabela 2).

\begin{tabular}{|l|l|}
\hline Kompetencje początkujących nauczycieli & $\begin{array}{l}\text { Konceptualizacja kompetencji przez badanych } \\
\text { początkujących nauczycieli }\end{array}$ \\
\hline Umiejętności językowe & Pewność swojej wiedzy językowej. \\
\hline Umiejętność nauczania & $\begin{array}{l}\text { Sposoby nauczania: sprawności, ćwiczenia, używanie } \\
\text { języka obcego. } \\
\text { Promowanie autonomii uczenia się. } \\
\text { Brak przygotowania do nauczania w sytuacjach } \\
\text { trudnych. }\end{array}$ \\
\hline Utrzymywanie dobrych relacji z uczniami & $\begin{array}{l}\text { Problemy z dyscypliną i rozwiązania. } \\
\text { Relacje interpersonalne a cechy nauczyciela. } \\
\text { Ocenianie. }\end{array}$ \\
\hline $\begin{array}{l}\text { Utrzymywanie dobrych relacji z innymi } \\
\text { pracownikami szkoły }\end{array}$ & $\begin{array}{l}\text { Świadome „trzymanie się z boku”. } \\
\text { Relacje z kolegami: dobór kolegów. } \\
\text { Relacje z dyrekcją. }\end{array}$ \\
\hline Utrzymywanie dobrych relacji z rodzicami & $\begin{array}{l}\text { Współpraca. } \\
\text { Konflikty. }\end{array}$ \\
\hline Umiejętności organizacyjne & $\begin{array}{l}\text { Przygotowywanie się do lekcji. } \\
\text { Udział w zajęciach pozalekcyjnych. }\end{array}$ \\
\hline $\begin{array}{l}\text { Umiejętność dokonywania refleksji, samo- } \\
\text { świadomość }\end{array}$ & $\begin{array}{l}\text { Aspiracje własne. } \\
\text { Aspekty wychowawcze w pracy nauczyciela. } \\
\text { Umiejętność dostrzegania sprzeczności. }\end{array}$ \\
\hline Samodzielne podejmowanie decyzji & $\begin{array}{l}\text { Rodzaje samodzielnych decyzji nauczyciela: poziom } \\
\text { klasy/ szkoły, dotyczące nauczyciela/innych. }\end{array}$ \\
\hline Rrytyka braku przygotowania w trakcie studiów. \\
\hline
\end{tabular}

Tabela 2: Mapa sposobów rozumienia kompetencji przez początkujących nauczycieli.

Uzyskane wyniki ujawniają zarówno mocne strony przygotowania początkujących nauczycieli do wykonywania swojej roli, jak również przeszkody hamujące odniesienie pełnego sukcesu dydaktycznego. Zrekonstruowane koncepcje znaczeń wyróżnionych kompetencji odsłaniają pewne trendy w myśleniu nauczycieli w pierwszym roku pracy, wśród których niektóre można uznać za pozytywne i sprzyjające pracy nauczyciela, zaś inne negatywne i utrudniające ją.

Kompetencją odróżniającą nauczyciela języka obcego od nauczycieli innych przedmiotów jest znajomość nauczanego języka. Sprawne posługiwanie się nauczanym językiem we wszystkich sprawnościach i podsystemach wzbudza podziw, szacunek i niekiedy chęć imitacji ze strony uczniów. Moc tego argumentu jest tak silna, że wciąż istnieją przekonania, iż dobra znajomość języka obcego nauczyciela czyni z niego równie skutecznego dydaktyka. Wywiady z nauczycielami pozwoliły na uchwycenie jednej kategorii wyrażającej się w „pewności własnej wiedzy językowej”. Badani nauczyciele z dużym przekonaniem odnoszą się do swojej dobrej kompetencji językowej wyma- 
ganej na nauczanym przez nich poziomie, a połowa z nich wyraża pragnienie większych wyzwań językowych. Badani odpowiadali:

Nie wiem, czy zostanę w szkole. Nudzę się. Chciałbym większe wyzwanie. [w 1] W sumie chciałabym uczyć czegoś trudniejszego. Czwarte klasy to alfabet, liczenie do 30, podstawowe czasy. [w 3]

Po tych kilku miesiącach nie rozwinęłam się pod względem angielskiego. Mówiłam cały czas po angielsku, ale to nie jest to, co chciałabym. Poznałam tylko nazwy niektórych rzadkich zwierząt. [w 6]

Warto dodać, że nauczyciele wybrani do badania nie pracują w dużych metropoliach i w swoich środowiskach uchodzą za „ekspertów” językowych, co można dobrze odczytać w poniższym przykładzie:

Kiedyś przyjeżdżam rano do szkoły na dyżur, a pani dyrektor przychodzi i mówi: „Mam dla ciebie bojowe zadanie. Dzisiaj przyjeżdżają Amerykanie, będzie spotkanie z całą szkołą i o 11.00 będziesz tłumaczył. Gdybym wcześniej wiedział, przygotowałbym się. Ale spotkanie było i tłumaczyć musiałem. Poradziłem sobie. Spodobało mi się. I dostałam ofertę pracy zleconej. [w 1]

Jedna z nauczycielek zdaje sobie sprawę, że jej wiedza językowa jest wystarczająco dobra w konkretnej wiejskiej szkole, gdzie jest jedyną nauczycielką języka angielskiego, dla jej uczniów i ich rodziców, którzy nie potrafią ocenić prawdziwej kompetencji językowej. Takie przyznawanie się do własnych niedociągnięć nie jest jednak popularne i można powiedzieć, że badani są zadowoleni ze znajomości języka niezbędnej na etapie, na którym nauczają.

O umiejętności nauczania często decyduje duży repertuar i dobór technik dostosowanych do wieku, potrzeb i oczekiwań uczniów, równomierna koncentracja na wszystkich sprawnościach i podsystemach, jak najczęstsze posługiwanie się językiem docelowym, a także wdrażanie do autonomii uczenia się. Wśród ulubionych strategii sprawdzających się w pracy nauczycieli, wymienionych przez respondentów, znalazły się karty obrazkowe i gry pamięciowe do nauczania słownictwa, dryle językowe, stawianie punktów za aktywność na każdej lekcji, a także częste powtarzanie, zachowanie konsekwencji ze strony nauczyciela, jak również wykorzystanie tekstów na rozwijanie słuchania oraz ćwiczeń gramatycznych, dzięki którym młodzież dyscyplinuje się. Na pytanie o wykorzystanie konkretnych sprawności i podsystemów języka, badani wymienili czytanie (2 osoby), słownictwo (wszyscy), mówienie (2 osoby), zaś pisaniu poświęcano najmniej uwagi. Dwie osoby przeznaczają fragmenty lekcji na ćwiczenia fonetyczne, aczkolwiek nieregularnie, zaś jedna 
wprowadza słownictwo na wzór swojego nauczyciela z uczelni polegające na, jak to określa, zabawie językiem.

Nauczyciel gramatyki na uczelni lubił bawić się językiem i zaraził mnie tym. Przy wprowadzaniu jakiegoś słowa, podawał podobne - synonimy, czasowniki frazowe, nawet 10 przykładów. Jak wprowadzam „look", automatycznie pytam: „A wiecie, co znaczy 'look for'? A 'look at’? Sprawia mi to ogromną przyjemność. Zanurzam się wtedy w języku, widzę sam język. [w 1]

Zapewnienia nauczycieli nie zawsze pokrywały się z obserwacją ich rzeczywistych zachowań na lekcji, gdyż tylko w przypadku połowy można mówić o systematycznym stosowaniu języka angielskiego podczas pracy na lekcji. Prawie wyłączne prowadzenie lekcji w języku angielskim miało miejsce tylko w dwóch przypadkach: szkole społecznej, w której przykłada się bardzo dużą wagę do tego przedmiotu, oraz na lekcji nauczycielki wyjątkowo zmotywowanej do utrzymania pracy. Zapytana o autonomię, ta sama nauczycielka odpowiada:

Staram się wprowadzać autonomię. Jest to ważne. Rozwijać świadomość - inni nauczyciele nie robią tego w ogóle. Kiedyś dziecko spytało się mnie” „Co? Ja mam decydować, tak jak dorosły? Przecież nie jestem nauczycielem. Na początku trzeba wprowadzać ćwiczenia na różne sprawności, pytać, co jest dla nich najtrudniejsze. Niełatwe na początku, ale po roku, dwóch, na pewno są efekty. [w 4]

Wszyscy pozostali deklarują wiarę w autonomię ucznia, ale za przykłady wyłącznie podają umożliwianie uczniom dokonywania wyboru odnośnie do rodzaju lub ilości pracy domowej. Połowa badanych ujawnia brak przygotowania do nauczania języka obcego w sytuacjach problematycznych (np. co robić, gdy uczniowie prezentują prawie zerową wiedzę z języka angielskiego w gimnazjum „na wejściu”, a należy kontynuować nauczanie, gdyż inaczej nauczyciel nie zdąży zrealizować programu). Takie stwierdzenia oznaczają, że respondenci mają świadomość i, być może, wolę rozwijania autonomii ucznia i prowadzenia lekcji w języku angielskim, ale w realizacji przeszkadzają im warunki kontekstualne - braki w kompetencji językowej uczniów niedorównujące wiedzy oczekiwanej na danym etapie uniemożliwiające nauczycielowi prowadzenie lekcji w języku angielskim bądź samodzielną naukę uczniów.

Za gwarancję sukcesu dydaktycznego często uchodzą dobre relacje nauczyciela z uczniami. Wśród konceptualizacji tej kompetencji pojawił się motyw dyscypliny, relacji interpersonalnych wpływających na postrzeganie uczniów przez nauczyciela, jak również problem oceniania uczniów. Prawie wszyscy respondenci doświadczyli problemów z dyscypliną uczniów, najczęściej w postaci głośnego zachowania, choć wymieniono także stosunkowo 
mało poważne przypadki łamania reguł szkolnych, takie jak bierność, brak zaangażowania, spóźnianie się, zajmowanie się na lekcji innymi sprawami niż nauka. Ponieważ wszyscy nauczyciele z tego typu zachowaniem mieli do czynienia wielokrotnie, wypracowali własne rozwiązania radzenia sobie z zakłócającymi tok lekcji postawami uczniów. Jako efektywne sposoby radzenia sobie z brakiem dyscypliny na lekcji wymieniono: wykorzystanie gwizdka, aby nie nadwerężać głosu, w przypadku małych grup wymuszenie siedzenia w jednym rzędzie przed nauczycielem lub w pojedynczych ławkach, aby nie mieć bliskiego towarzystwa niesfornego kolegi, karanie brakiem obejrzenia ulubionej kreskówki podczas lekcji, zadawanie dodatkowej pracy domowej w postaci tłumaczenia tekstu lub wstawianie „jedynek" za rozmawianie na lekcji. Choć ostatni sposób rozwiązań budzi wątpliwości, badany nauczyciel przyjmuje następujące stanowisko:

Nic innego na nich nie działa. Uwaga nie działa, kara w postaci przetłumaczenia tekstu nie działa, tylko jedynki. Chcąc nie chcąc muszę robić coś, żeby ich uspokoić. Na początku tak nie było, teraz jest coraz częściej. Jedyny sposób. [w 1]

Ale wśród badanych, pojawiła się także wypowiedź, w której nauczycielka mówi:

Nie mam problemów z dyscypliną. Kiedy zaczyna się coś dziać, rozmawiam z nimi. Różnie jest, ale nie poddaję się. [w 5]

O utrzymywaniu dobrych relacji z uczniami świadczą także wyobrażenia początkujących nauczycieli na temat roli nauczyciela względem uczniów. Dla sześciorga badanych, nauczyciel jest kojarzony z osobą, która: 1) potrafi zaciekawić nauczanym przedmiotem, 2) ma własny styl zjednujący szacunek uczniów, 3) jest skarbnicą wiedzy, która zarazem wykonuje syzyfową pracę dobrze, gdyż czyni to z miłości do nauczania, 4) naucza w taki sposób, aby uczeń sam docierał do wiedzy, 5) osoba, która znosi problemy, gdyż jest cierpliwa, 6) wykonuje taką samą pracę, jak inni. W ramach tak charakteryzowanej koncepcji znaczeń, zauważa się dużą różnorodność obejmującą dobre przygotowanie merytoryczne, uwzględnianie potrzeb uczniów, autonomiczność wyrażającą się w posiadaniu niepowtarzalnego stylu i promowaniu autonomii ucznia, jak również ofiarność i pragmatyczność. Choć ważne jest, kto mówi dane słowa i w jakim kontekście pracuje, nakreślony sposób rozumienia nauczania odsłania zarówno osobiste próby poszukiwań młodych nauczycieli, jak i bezrefleksyjne godzenie się na obraną rzeczywistość, „znoszenie problemów” czy „wykonywanie pracy”. 
Kolejną wyłonioną kompetencję stanowi umiejętność utrzymywania dobrych relacji z innymi pracownikami szkoły, a jej przejawy to relacje z innymi nauczycielami oraz zwierzchnikami nauczycieli. W wypowiedziach dominowały informacje o dobrych relacjach ze współpracownikami, ale najczęściej dotyczyły one przyjaznych kontaktów z nauczycielami w podobnym wieku i krótkim stażu pracy. Moore (2008: 35) twierdzi, że wsparcie innych młodych nauczycieli, które najczęściej przybiera pomoc nieformalną, może być nieocenione w przetrwaniu pierwszego roku pracy. Kontakty ze starszymi współpracownikami generowały konflikty, czego wyrazem jest przykładowa poniższa wypowiedź.

Kiedyś na radzie pedagogicznej powiedziałam, że jeden z uczniów nie musi zdać. Wtedy jedna z pracujących emerytek powiedziała: 'Nie będę słuchać stażystek. Po co nam kłopoty, lepiej go przepuścić, niech w gimnazjum męczą się z nim'. A ja tylko proponowałam. [w 4]

Wypowiedź badanej świadczy o tym, że problemy z innymi nauczycielami mogą oznaczać barierę pokoleniową, którą młody nauczyciel odczytuje jako dyskryminację, zawiść lub kompleks ze strony osoby starszej. Rosin (2010: 89) uważa, że młodzi nauczyciele zwykle rozpoczynają pracę z entuzjazmem, często „porażają” starszych pracowników swoim zapałem, a ponieważ nikt nie toleruje wyróżniania się z tłumu przez zbyt długi czas, następuje „równanie do szeregu”.

Relacje ze zwierzchnikami uważano za dosyć dobre i dyrektorzy należeli do tych osób, którym nauczyciele zgłaszali swoje problemy. Nauczyciele odpowiadali:

Pani dyrektor idzie mi na rękę. Jak podjąłem dodatkowe studia i plan mi się zmienił, nie było problemu, żeby zmienić plan w szkole. Wtedy pani dyrektor dała mi dwie godziny z rzędu, chociaż tego zwykle nie stosuje. [w 1]

Miałam problem z matką ucznia, która porównywała mnie do poprzedniej nauczycielki i twierdziła, że za dużo zadaję, chodzę na zwolnienia i powinnam się zastanowić, czy chcę zostać nauczycielką. Powiedziała, że powinna pójść do dyrektora, ale tego nie zrobi. Więc ja poszłam do dyrektora i naświetliłam tę sprawę. Wspólnie z dyrektorem staraliśmy się rozwiązać problem tej pani. [w 6]

Inną istotną kompetencją w zawodzie nauczyciela jest, zasygnalizowana powyżej, umiejętność utrzymywania relacji z rodzicami. Wypowiedzi nauczycieli w większości wskazują na poprawne relacje, ale pojawiły się także inne przykłady podobne do tego poniżej: 
Kordian notorycznie nie nosił podręcznika, zeszytu, nic nie robił, więc napisałam kartkę do rodzica, że chciałabym się spotkać. I spotkałam się, już tego samego dnia raczył mnie odwiedzić tata Kordiana i miał mi wiele do zarzucenia: że źle uczę, za dużo wymagam, nie korzystam z ćwiczeń, bo Kordian nie ma tam nic zapisane, ale ja też miałam parę słów do powiedzenia odnośnie nauki i zachowania Kordiana, na co tata stwierdził, że z nim porozmawia. [w 5]

Wśród wyłonionych kompetencji początkujących nauczycieli pojawiły się umiejętności organizacyjne, a ich przejawy to przygotowywanie się do lekcji oraz udział w zajęciach pozalekcyjnych. Większość nauczycieli planuje lekcje długofalowo, co przejawia się w następujących wypowiedziach:

Lubię wszystko poukładać, przygotować materiały. Może było trochę stresująco we wrześniu, ale dałam radę. Mam wielki karton z obrazkami. Podzieliłam wszystko wcześniej, mnóstwo zabawek, samochodów po rodzinie. Przygotowałam się na dwa miesiące naprzód. [w 4]

Zawsze starałam się być i jestem zorganizowana. Lubię zaplanować, rozpisać sobie, co z jaką klasą chcę zrobić, jakie ćwiczenia, jaką zadać pracę domową. Zawsze staram się przemyśleć, choćby krótko. [w 3]

Na wybór zajęć pozalekcyjnych nauczyciela składał się szkolny repertuar imprez, a więc wycieczki, konkursy, zajęcia „karciane”. Poniższe wypowiedzi wskazują, które z nich odbyły się z inicjatywy samych nauczycieli i z jakim skutkiem:

Lubię się angażować. Zaoferowałam się, że przyjdę na Wigilię, że nie jest to problem dla mnie. Dzień wolny to nie jest dzień wolny od pracy, czego wielu nauczycieli nie rozumie, a tylko od zajęć. [w 4]

Dyrektor już na początku roku chciał pomysł na „karciane”. Wzięłam język niemiecki od podstaw, nie nauczany w szkole. Było to raz w tygodniu, nie było wywieszki, ale dużo osób chodziło, zaczepiało mnie, czy mogą się zapisać. Dyrektor też był zadowolony, że szkoła oferuje dodatkowy język. [w 2]

Wśród wypowiedzi ujmujących kompetencje nauczycieli wyłoniła się także umiejętność dokonywania refleksji. Zaobserwowane zjawisko przejawia się głównie w komentarzach wyrażanych pod adresem własnego rozwoju zawodowego, lecz także dotyczy aspektów wychowawczych pracy nauczyciela oraz dostrzegania sprzeczności w różnych wymiarach pracy szkoły. Nauczyciele wówczas odpowiadali:

Bardzo lubię literaturę. Może kiedyś uda mi się zrealizować marzenie - wykładać literaturę amerykańską. Duży wpływ na to miał mój profesor od literatury na uczelni. [w 1] 
Chciałabym wyrobić w uczniach nawyk, że w momencie wejścia na zajęcia, sami wiedzą, po co przyszli i pracują. Od początku do końca wypracowana lekcja. Chciałabym też być pewna siebie w tym, co robię, tak popłynąć. Czasami boję się, że nie będę w stanie uzasadnić swoich decyzji, na przykład na piśmie. Ja jeszcze dryfuję. [w 5]

W szkole przeraża mnie chaos. Nie ma zgrania, reguł. Obserwowałam kiedyś lekcję koleżanki matematyczki i byłam przerażona. Nigdy więcej. Nie potrafiłabym powiedzieć do ucznia „Jesteś głupi” i nie chciałabym, aby uczeń podszedł do mnie i tak do mnie mówił. Miałam dosyć. [w 5]

Inną wyłonioną kompetencją jest samodzielne podejmowanie decyzji przez nauczycieli. Ta umiejętność wydaje się szczególnie istotna w czasach, gdy paradygmat sztywnej szkolnej transmisji wiedzy zdewaluował się, a rola współczesnego nauczyciela uległa modyfikacji. Przytoczone znaczenia tej kompetencji w rozumieniu badanych wskazują na rodzaje ich decyzji, które odnoszą się do samego nauczyciela albo innych osób oraz obejmują różne zakresy - poziom klasy, w której nauczyciel prowadzi zajęcia czy poziom szkoły uwzględniający szersze oddziaływanie.

Kwestia podręczników? Patrzyłem na podręczniki z innych wydawnictw, musiałem przeanalizować. Czy wymieniać na inne, które aż tak wiele nie wniosą, czy nie? Przeważył koszt i podręczniki zostały, ale zmodyfikowałem - wyrzuciłem ćwiczenia, a zostawiłem książkę do gramatyki, gdzie są też ćwiczenia na słownictwo, a nawet na mówienie. [w 1]

Dyrekcja stwierdziła, że uczniowie nie pojadą na żadną wycieczkę za złe zachowanie. Ja się zbuntowałam, bo moja klasa była naprawdę grzeczna i dlaczego mają być karani za zachowania innych klas. Pojechałam do szkoły w sąsiedniej wsi i zorganizuję wycieczkę do Torunia z inną szkołą. Cieszę się z takiej samodzielnej decyzji. [w 5]

Ostatnią wyróżnioną kompetencją są praktyczne umiejętności związane z pracą w szkole i odnoszą się do radzenia sobie młodych nauczycieli z wymogami formalnymi. Wyłoniona kompetencja jest o tyle ważna, że odpowiedzi badanych dotyczą pytania o obszar zbyt nikłego przygotowania do pracy nauczyciela w okresie studiów. Stanowiska badanych są jednostronnie krytyczne w tej kwestii, co ilustrują następujące wypowiedzi:

Choć wiedza nauczyciela nie jest mi obca, bardzo bałam się o formalności (sprawozdania, plany wynikowe). Sama robiłam plany, liczyłam godziny na cały rok, uczyłam się „w biegu". [w 4]

Po hospitacji pani dyrektor przyczepiła się do mojego konspektu, że zbyt ogólnikowy, że jeszcze inne cele trzeba było uwzględnić niż te, które mieliśmy na lek- 
cjach metodyki. Nie pamiętam dobrze, ale chyba 7 różnych celów. Miałam problem z wypełnieniem. Inni nauczyciele z kolei mówili, że za dużo celów nie można wpisywać, bo później pani dyrektor daje minusy za brak realizacji celów. [w 3] Dla mnie dokumentacja była nowością. Przez długi czas zaznaczałam na zielono kartkówki, aż kiedyś zwrócono mi uwagę. [w 5]

\section{Etap II}

Etap drugi badania obejmował porównanie kompetencji nauczyciela wyróżnionych w modelu KARDS do kompetencji i znaczeń wyodrębnionych przez badanych nauczycieli. Próbę takiego przyporządkowania przedstawia tabela 3 poniżej.

\begin{tabular}{|l|l|}
\hline Kompetencje KARDS & Kompetencje wg nauczycieli \\
\hline Wiedzieć & $\begin{array}{l}\text {-Umiejętności językowe } \\
\text {-Umiejętność nauczania }\end{array}$ \\
\hline Analizować & - Umiejętność nauczania, \\
\hline Rozpoznawać & $\begin{array}{l}\text {-Umiejętność dokonywania refleksji } \\
\text {-Samodzielne podejmowanie decyzji }\end{array}$ \\
\hline Działać & -Umiejętności organizacyjne \\
\hline Widzieć & $\begin{array}{l}\text {-Utrzymywanie dobrych relacji z uczniami } \\
\text {-Utrzymywanie dobrych relacji z rodzicami } \\
\text {-Utrzymywanie dobrych relacji z innymi } \\
\text { pracownikami szkoły }\end{array}$ \\
\hline
\end{tabular}

Tabela 3: Kompetencje KARDS a kompetencje nauczycieli według badanych.

Choć wyłonione w toku badań koncepcje kompetencji dały się uporządkować i wpisać w model KARDS, nasuwa się kilka słów komentarza. Kategoria „wiedzieć" dobrze odpowiada wyróżnionym umiejętnościom językowym i umiejętnościom nauczania według nauczycieli, gdyż mieści się w niej zarówno znajomość nauczanego języka obcego, jak również teorii uczenia się i nauczania języków obcych. Kategoria „analizować” zawiera w sobie część kompetencji składających się na poprzednią kategorię, ponieważ w kompetencji KARDS jest miejsce na „utrzymywanie motywacji uczniów do uczenia się" oraz „wdrażanie do autonomii”, odpowiadające „umiejętności nauczania”, na przykład, promującego autonomię uczenia się. Można z dużą pewnością przyjąć, że kategoria „rozpoznawać", odnosząca się do rozwijania świadomości nauczyciela na temat własnej tożsamości, przekonań i wartości, dobrze przekłada się na dwie kompetencje wyłonione z wywiadów nauczycieli - „umiejętność dokonywania refleksji” oraz „samodzielne podejmowanie decyzji”. Kolejna kompetencja wyróżniona w modelu KARDS to „działanie” oznaczające w rozumieniu Kumaravadivelu (2012) stwarzanie okazji do uczenia się, inspirowanie osobistych transformacji uczniów oraz 'teoretyzowanie' nauczyciela. W znaczeniach kompetencji wyłonionych z badania, nauczyciele zwracają uwagę na umiejętności organizatorskie, wśród 
których prowadzenie zajęć pozalekcyjnych może doprowadzać do transformacji uczniów. Ostatnia kompetencja nauczyciela okresu globalizacji to umiejętność „patrzenia” z perspektywy ucznia, nauczyciela oraz obserwatora. Dlatego utrzymywanie dobrych relacji z trzema podmiotami szkoły - uczniami, współpracownikami i rodzicami -znalazło tutaj miejsce.

\section{Dyskusja i wnioski}

Zgromadzone na podstawie całego materiału badawczego wyniki obejmujące zasadnicze kategorie kompetencji $z$ ich znaczeniami reprezentowanymi przez badanych i odniesionymi do modelu KARDS są wielowątkowe, ale pozwalają na dokonanie wstępnych refleksji na temat tego, jak wyróżnione znaczenia mają się do propozycji Kumaravadivelu, a więc kim są początkujący nauczyciele języków obcych, jakimi kompetencjami dysponują, a jakich umiejętności im brak. Dlatego można przyjąć, że poniższa dyskusja, ograniczona do najczęściej wymienianych w badaniu lub najbardziej uderzających kwestii, jest próbą identyfikacji różnorodnych "odsłon” kompetencji nauczycieli na starcie kariery zawodowej według modelu KARDS.

Cieszy fakt, że początkujący nauczyciele odznaczają się dobrą znajomością języka obcego, na co wskazują opinie badanych, a sami nauczyciele narzekają na niewielkie wyzwania językowe w swoich placówkach oświatowych. Wciąż jeszcze nauczyciel funkcjonuje jako najważniejszy model językowy dla uczniów, a zatem powinien „występować w roli osoby kompetentnie posługującej się językiem obcym" (Komorowska, 2005: 105). Z drugiej strony, warto wspomnieć, że kompetencje językowe oceniali nauczyciele uczący w szkołach podstawowych i gimnazjalnych, gdzie z pewnością poziom znajomości języka angielskiego, jakim dysponuje nauczyciel, jest wystarczający. Medgyes (1994: 53) ostrzega, iż na dłuższą metę język nauczycieli nauczających tylko grupy początkujące zaczyna, jak to określa „rdzewieć”, ponieważ nauczyciele nie są zmuszani do jego doskonalenia.

Kompetencja metodyczna obejmująca znajomość teorii uczenia się i nauczania języków, jak również zarządzanie uczeniem się w klasie również została pozytywnie zauważona w badaniu. Choć respondenci wywiadów podawali tylko przykłady popularnych technik nauczania, raczej nie odnieśli się do własnych braków w tym zakresie, z wyjątkiem jednego przypadku, gdy nauczyciel zwrócił uwagę na nieumiejętność postępowania w sytuacjach problematycznych. ${ }^{1}$ Można dodać, że kompetencje szczegółowe budujące wyróżnioną tu

\footnotetext{
${ }^{1}$ Problem dotyczył nieumiejętności nauczania uczniów pierwszej klasy gimnazjalnej, którzy reprezentowali tak niski poziom znajomości języka, że nauczyciel powinien rozpocząć z nimi pracę od początku. Na to jednak nie pozwalał realizowany w gimnazjum program.
} 
kompetencję „wiedzieć”, to jest znajomość języka angielskiego, teorii uczenia i nauczania, jak również przełożenie tej wiedzy na pracę w klasie, zawsze istniały w programach kształcenia nauczycieli języków obcych i stąd nie dziwi ich pozytywny odbiór przez respondentów. Nauczyciele widzą siebie w roli kompetentnego dydaktyka przedmiotu, przekazującego wiedzę i sprawnie zarządzającego procesem lekcyjnym.

Kompetencja związana z analizowaniem, a więc diagnozowaniem potrzeb, utrzymywaniem motywacji i wdrażaniem autonomii nie została już tak jednoznacznie dostrzeżona. Na temat diagnozowania potrzeb ucznia nie było wzmianki respondentów, choć „podobieństwo mentalne” nauczycieli starszych uczniów może skutkować wyborem interesujących dla uczniów tematów lekcji. Sami nauczyciele twierdzą, że są świadomi konieczności wprowadzania autonomii, znają termin, ale podejmują ten temat dopiero zapytani o odpowiedź. Z kolei motywacja wywołuje skojarzenie z motywowaniem ucznia od początku, a nie koniecznością utrzymywania motywacji ucznia, tak wiele razy podkreślaną w publikacji Dörnyei'a (2002). Z badania także wynika, że młodzi nauczyciele, pełni zapału i determinacji, mają idealistyczne przekonania na temat nauczania i nie zdają sobie sprawy, że na przykład, na autorytet młodzieży należy zapracować. Bardzo im zależy na byciu lubianym przez uczniów i zdarza się, że swoją popularność przedkładają nad stanowczość, w krótkim czasie doświadczając problemów z dyscypliną. W konsekwencji prowadzi to do prób wprowadzania autorytarnych form utrzymywania dyscypliny, spadku popularności wśród podopiecznych, a także narażenia na opór i prowokacje uczniów. Nauczyciel karzący ucznia jedynkami za złe zachowanie prawdopodobnie nie jest świadomy, iż jego autorytet na tym nie zyskuje, a sam fakt bycia nauczycielem i nawet chęć nauczenia mogą nie wystarczyć, aby cieszyć się szacunkiem uczniów. Ostrowska (2010: 395) twierdzi, że nawet największe autorytety prędzej czy później ulegają przemianom i raz uznane wymagają potwierdzania w różnym stopniu i zakresie. To, co mogło być skuteczne do uzyskania autorytetu w przeszłości (strach przed złą oceną u wymagającego nauczyciela), nie jest rozwiązaniem długofalowym, a raczej autorytetem ujarzmiającym (Błędowska, 2010: 307), opartym na władzy i egoizmie nauczyciela (myśleniu typu „uspokój się, bo ja chcę prowadzić lekcję”). Prawidłowa droga budowania autorytetu nauczyciela prowadzi poprzez jego wysiłek w realizację potrzeb i dążeń uczniów, przyjmowanie współodpowiedzialności za ich porażki, zaś straszenie złymi ocenami na pewno nie poprawi kontaktów na linii uczeń nauczyciel. Tak więc, kompetencja „analizować” nie zawsze jest przestrzegana przez omawianych tu respondentów. Na swój sposób rozumienia wprowadzają autonomię uczniów, raczej nie diagnozują ich potrzeb, przyjmując, że program nauczania 
jest ważnym zadaniem do realizacji, a motywację uczniów starają się utrzymać poprzez dyscyplinowanie, w tym złymi ocenami.

Kompetencja ogólna polegająca na „rozpoznawaniu” własnych nauczycielskich tożsamości, samoświadomości i refleksji została sprowokowana przez badaczkę w wywiadach nauczycieli. Wszystkie nauczycielki ${ }^{2}$ uczestniczące w badaniu "noszą pracę do domu", przygotowując się do zajęć, poprawiając sprawdziany, rozmyślając o aspektach wychowawczych pracy z uczniem, zaś niewiele zastanawiając się nad reprezentowanymi przez siebie przekonaniami czy wartościami. Tylko jedna z badanych potrafiła wyartykułować styl nauczania, który chciałaby opanować, nazywając po imieniu własne niedociągnięcia, sprzeczności występujące w szkole, których jest świadoma oraz konieczność i możliwości poprawy tych aspektów. Można przyjąć, że poświęciła im swój namysł, próbując także opracować strategie działania. Pozostali raczej nie zastanawiali się na tym, co oni przekazują uczniom swoją postawą nauczyciela, jakie wartości podświadomie promują i w jaki sposób mogą rozwijać tożsamość zawodową nauczyciela. Dla dwóch osób nauczanie w szkole było jedną z trzech prac wykonywanych regularnie, dla dwóch praca kojarzyła się z rutynowym zajęciem od 8.00 do 15.00 , zaś kolejne dwie nauczycielki nie rozpatrywały pracy w szkole jako pracy „na zawsze”. Takie postawy sugerują, że żaden z badanych respondentów nie odznaczał się tożsamością osiągniętą (Marcia, 1967), zaś tożsamości nadane, moratoryjne lub rozproszone stały się obecnie normą w zawodzie nauczyciela. To wszystko oznacza, iż dużo jest do zrobienia w ramach tej kompetencji, gdyż wiele trudnych sytuacji pedagogicznych dałoby się uniknąć, gdyby nauczyciel analizował skutki swoich działań w sytuacji szkolnej i kierował swoją refleksję na siebie, a nie tylko na ucznia (Czykwin, 1995: 120).

Kompetencje szczegółowe tworzące kompetencję ogólną „działania” to stwarzanie okazji do uczenia się, inspirowanie transformacji uczniów i swoich oraz teoretyzowanie i prowadzenie szeroko pojętego dialogu. Wybór teoretyzowania, jako kompetencji szczegółowej jest ciekawy, gdyż coraz częściej podkreśla się fakt, iż „umiejętności praktyczne nauczyciela mają w wysokim stopniu charakter teoretyczny" (Kwiatkowska, 2010: 82). Kompetencja ta nawiązuje do umiejętnego posługiwania się dydaktyką języka obcego, umiejętnością utrzymywania dobrych kontaktów z uczniem oraz kompetencją analizowania i dokonywania refleksji nad własną pracą pedagogiczną. Zarówno stwarzanie okazji do uczenia się, jak i inspirowanie transformacji uczniów przebiega $w$ różnym zakresie u badanych nauczycieli, ale warto podkreślić $w$ tym miejscu wagę zajęć pozalekcyjnych, w tym przygotowań do konkursów językowych, organizację wycieczek, udział w projektach językowych. Wymaga się, aby po-

\footnotetext{
${ }^{2}$ Nie dotyczyło to badanego mężczyzny.
} 
czątkujący nauczyciele, rozpoczynający staż zawodowy, właśnie w tych obszarach „zaistnieli”, wykorzystując sytuacje nieformalne do uczenia się i jednocześnie doprowadzając do metamorfozy ucznia jako użytkownika języka obcego.

Ostatnia kompetencja w modelu KARDS, polegająca na „patrzeniu” z różnych perspektyw, została dostrzeżona przez badaną grupę. Początkujący nauczyciele raczej nie mają większych problemów z rodzicami niż nauczyciele w innym przedziale wiekowym, ale może wystąpić bariera pokoleniowa w przypadku braku chęci pójścia na kompromis młodego nauczyciela (rozumienie typu „Dlaczego to ja mam ustąpić, gdy wiem, że mam rację?”) z nauczycielem z długim stażem pracy (rozumienie typu „Młodzi myślą, że wszystko wiedzą, panoszą się swoją mądrością, a brakuje im ogłady i doświadczenia."). Na pewno ciągła dbałość o dobre umiejętności komunikacyjne mające na celu ułatwienie nawiązywania i utrzymywania kontaktów interpersonalnych przydałaby się młodym adeptom zawodu nauczyciela.

Model kształcenia nauczycieli KARDS pomija kwestie przygotowania praktycznego związanego z radzeniem sobie z procedurami, dokumentacją szkolną czy nauczaniem w sytuacjach nietypowych. W referowanym tu badaniu wszyscy respondenci jednogłośnie narzekali na zaniedbania w tym obszarze w programach oferowanych w polskich uczelniach. Próbując zrozumieć głosy nauczycieli można przyjąć, iż każdy nauczyciel chciałby być kompetentny i wiedzieć na temat uczniów, nauczania, szkoły, tuż na starcie pracy zawodowej tyle, ile wie nauczyciel z długoletnim stażem. Jest to pragnienie zrozumiałe, ale czy zawsze zasadne? Zawód nauczyciela kojarzy się z nieokreślonością, brakiem pewności, problematycznością, wieloznacznością pełnionych ról (Konarzewski, 2002: 152). Toczy się na tak wielu płaszczyznach, że trudno wtłoczyć go w sztywne ramy, na przykład ról do spełnienia. Często mówi się, że mądrość nauczyciela ujawnia się w wątpliwości, wahaniu, dostrzeganiu sprzeczności, a nie w jednoznaczności, pewności czy braku rozterek. Chcąc nie chcąc, nauczyciel w trakcie każdej lekcji podejmuje mnóstwo decyzji wykluczających się, jak te, czy zadać czy nie zadać pracę domową, ocenić wysiłek czy zdolności ucznia, poprawić czy zignorować błąd (Werbińska, 2009). Dlatego może dziwić fakt, że z pewności działania czyni się zaletę, jakby zapominając, że praca nauczyciela jest oksymorficzna, gdyż dotyczy człowieka. Oznacza to, że mnóstwo w niej dylematów i konfliktów, że nie jest możliwe przygotowanie nauczycieli na każdą sytuację dydaktyczno-wychowawczą oraz, jak pokazuje Kwiatkowska (2010: 78), że miarą wartości wiedzy w wyposażeniu zawodowym nauczyciela jest, wspomniana wcześniej, ,jej moc inferencyjna”. Być może, najważniejszą kompetencją nauczyciela jest robienie dobrego użytku z teorii indywidualnych nauczyciela (Polak, 1999; Werbińska, 2004), posiadanie wiedzy osobistej, two- 
rzonej w biegu, którą nauczyciel nie dysponuje, lecz potrafi wygenerować $z$ wiedzy i kompetencji już posiadanych.

\section{Podsumowanie}

Opisane badanie mające na celu identyfikację kompetencji początkującego nauczyciela języka angielskiego w oparciu o model kształcenia KARDS dostarcza niezbyt optymistycznych wyników. Oprócz tradycyjnie nauczanych kompetencji studentów filologii angielskiej o specjalizacji nauczycielskiej, tj. kompetencji językowej i kompetencji metodycznej, brak jest wielu odniesień do kompetencji szczegółowych wyróżnionych przez Kumaravadivelu, często niedookreślonych, a dzięki temu umożliwiających nauczycielowi samodzielne podejmowanie decyzji. Warto pamiętać, że we współczesnych warunkach nie można już dalej patrzeć na edukację przez pryzmat powinności, cech czy ról nauczyciela, lecz z perspektywy oczekiwań czasów, w których przyszło nauczycielowi pracować (Kaniowski, 2010: 30). Model KARDS, skonstruowany z perspektywy 'po' jest takim modelem, gdyż oferuje myślenie o kompetencjach nauczycieli w kategoriach nieustannego stawania się, nabywania możliwości, rewidowania tego, co się wydarzyło z perspektywy tego, kim się jest. Sugeruje także, że najważniejszą kompetencją współczesnego nauczyciela może być umiejętność projektowania siebie w tym zawodzie, w której samoświadomość jest tak istotnym aspektem, że przesądza o jakości jego pracy.

\section{BIBLIOGRAFIA}

Andrews, S. 2007. Teacher Language Awareness. Cambridge: CUP.

Błędowska, M. 2010. „Autorytet jako czynnik (de)formujący proces wychowawczy?”.

[w:] Michalak, J. (red.). Etyka i profesjonalizm w zawodzie nauczyciela. Łódź: Wydawnictwo Uniwersytetu Łódzkiego. 301-314.

Borg, S. 2006. Teacher Cognition and Language Education. London-New York: Continuum.

Borg, S. 2012. "Current approaches to language teacher cognition research: A methodo-

logical analysis". [w:] Barnard, R. i A. Burns. (red.). Researching Language Teacher Cognition and Practice. Bristol-Buffalo-Toronto: Multilingual Matters. 11-29.

Bullough, R.V. 2009. Poczq̨tkujqcy nauczyciel. Gdańsk: GWP.

Czykwin, E. 1995. Samoświadomość nauczyciela. Białystok: Transhumana.

Dörnyei, Z. 2001. Motivational Strategies in the Language Classroom. Cambridge: CUP. Farrell, T. 2006. Succeeding with English Language Learners. A Guide for Beginning Teachers. Thousand Oaks, Ca.: Corwin Press.

Farrell, T. 2007. Reflective Language Teaching. London-New York: Continuum.

Farrell, T. 2008. Novice language Teachers. London: Equinox.

Garton, S. i Richards, K. 2008. Professional encounters in TESOL. Basingstoke: Palgrave. 
Johnson, K.E. 2009. Second Language Teacher Education. New York-London: Routledge. Johnson, K.E. i Golombek, P.R. 2002. Teachers' Narrative Inquiry as Professional Development. Cambridge: CUP.

Johnson, K.E. i Golombek, P.R. 2011. Research on Second Language Teacher Education. New York-London: Routledge.

Johnston, B. 2003. Values in English Language Teaching. Mahwah, NJ: LEA.

Kalaja, P., Menezes, V. i Barcelos, A.M.F. 2010. Narratives of Learning and Teaching EFL. Basingstoke: Palgrave.

Kaniowski, A. 2010. "Etyka I pedagogika. Etyczne aspekty pracy nauczyciela". [w:] Michalak, J. (red.). Etyka i profesjonalizm w zawodzie nauczyciela. Łódź: Wydawnictwo Uniwersytetu Łódzkiego. 13-48.

Komorowska, H. 2005. Metodyka nauczania języków obcych. Warszawa: Wydawnictwo Fraszka Edukacyjna.

Konarzewski, K. 2002. "Nauczyciel". [w:] Konarzewski, K. (red.). Sztuka nauczania. Szkoła. Warszawa: Wydawnictwo Naukowe PWN. 148-179.

Kumaravadivelu, B. 2012. Language Teacher Education for a Global Society. New York: Routledge.

Kwiatkowska, H. 2010. "Nauczyciel - zawód "niemożliwy", ale nieunikniony". [w:] Michalak, J. (red.). Etyka i profesjonalizm w zawodzie nauczyciela. Łódź: Wydawnictwo Uniwersytetu Łódzkiego. 67-86.

Męczkowska, A. 2002. Od świadomości nauczyciela do konstrukcji świata społecznego. Kraków: Impuls.

Marcia, J.E. 1967. „Ego identity status: Relationship to change in self-esteem, 'general maladjustment', and authoritarianism". Journal of Personality. 35: 118-133.

Medgyes, P. 1994. The Non-Native Teacher. Berlin: Max Hueber Verlag.

Moore, S. 2008. „Trained for teaching high school, poached for teacher training: A case study of a Cambodian English Teacher's first year of teaching in Cambodia". [w:] Farrell, T. (red.). Novice Language Teachers. Londyn: Equinox. 29-42.

Nowak-Łojewska, A. 2011. Od szkolnego przekazu do konstruowania znaczeń. Zielona Góra: Uniwersytet Zielonogórski.

Ostrowska, U. 2010. „Etyczne aspekty relacji mistrz-uczeń w edukacji akademickiej”. [w:] Michalak, J. (red.). Etyka i profesjonalizm w zawodzie nauczyciela. Łódź: Wydawnictwo Uniwersytetu Łódzkiego. 385-402.

Polak, K. 1999. Indywidualne teorie nauczycieli. Kraków: Wydawnictwo Uniwersytetu Jagiellońskiego.

Polok, K. 2010. Nauczyciel bilingwalny. Łask: Oficyna Wydawnicza LEKSEM.

Rosin, M. 2010. „Nauczyciel jako ofiara manipulacji”. [w:] Wróbel, A. (red.). Nauczyciel w krajach postsocjalistycznych jako sprawca i ofiara manipulacji. Łódź: Wydawnictwo Uniwersytetu Łódzkiego. 81-100.

Senior, R.M. 2006. The Experience of Language Teaching. Cambridge: CUP.

Schuck, S., Aubusson, P., Buchanan, J. i Russell, T. 2012. Beginning Teaching. Dordrecht- Heidelberg: Springer.

Sinclair, B., McGrath, I. i Lamb, T. (red.). 2000. Learner Autonomy, Teacher Autonomy: Future Directions. London: Longman. 
Kompetencje początkującego nauczyciela języka angielskiego w świetle modelu...

Werbińska, D. 2004. Skuteczny nauczyciel języka obcego. Warszawa: Fraszka Edukacyjna. Werbińska, D. 2009. Dylematy etyczne nauczycieli języków obcych na starcie kariery zawodowej. Warszawa: Wydawnictwo Fraszka Edukacyjna.

Werbińska, D. 2011. Developing into an Effective Polish Teacher of English. Słupsk: Wydawnictwo Naukowe Akademii Pomorskiej.

Woods, D. 1996. Teacher Cognition in Language Teaching. Cambridge: CUP.

Wysocka, M. 1998. Samoocena nauczyciela języka obcego. Warszawa: Energeia

Wysocka, M. 2003. Profesjonalizm w nauczaniu języków obcych. Katowice: Wydawnictwo Uniwersytetu Śląskiego.

Zawadzka, E. 2004. Nauczyciele języków obcych w dobie przemian. Kraków: Impuls. 